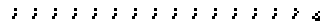

: Widya Akuntansi dan Keuangan

: Universitas Hindu Indonesia

Edisi Agustus 2020

\title{
ANALISIS PENGGUNAAN APLIKASI E-TICKETING BIOSKOP (M-Tix) DENGAN DIMENSI PENERIMAAN TEKNOLOGI
}

\author{
Gusi Putu Lestara Permana ${ }^{1}$ \\ I Gusti Ngurah Darma Paramartha ${ }^{2}$ \\ Ida Ayu Winda Juniari ${ }^{3}$ \\ 1,2,3 Universitas Pendidikan Nasional, e-mail : lestarapermana@undiknas.ac.id
}

\begin{abstract}
The aim of this research was analyze factors that user accept e-ticketing software called m-tix using contruct from Technology Acceptance Model (TAM). Data were collected using questionnaire. The sample in this study were 75 respondents, and respondents determine with purposive sampling method. Data were analyzed using several test such as : multiple linier regretion, goodness of fit test, partial significance test (t-test). All data was running in Statistical Package for the Social Sciences (SPSS) software for windows.

The results of this study was 1) percieved ease of use has a positive and significant effect on the use of m-tix. 2) percieved usefulness has a positive and significant effect on the use of m-tix. 3) trust has a positive and significant effect on the use of use of m-tix. 4) Self-efficacy has a positive and significant effect on the use of use of m-tix.
\end{abstract}

Keyword : percieved ease of use, percieved usefulness, trust, Self-efficacy, e-ticketing

\section{PENDAHULUAN}

Dalam perkembangan teknologi informasi saat ini, kecepatan, keamanan, dan kemudahan menjadi pertimbangan utama pengembangan sebuah sistem sehingga mengakibatkan persaingan yang semakin kompetetif. Ketatnya persaingan dan pesatnya perkembangan teknologi dan informasi yang ada menuntut suatu sistem yang lebih baik dan handal dalam menyelesaikan masalah.

Seiring dengan perkembangan teknologi yang semakin canggih dimana banyak sekali masyarakat yang disibukan dengan rutinitas dan pekerjaan sehari-hari untuk itu dibutuhkan nya suatu sarana untuk melepas semua masalah dari pekerjaan yang dilakukan dengan melakukan hiburan menonton film di bioskop. Perkembangan dunia perfilman sudah berkembang dengan cepat. Ini dapat dilihat dengan semakin banyaknya dunia perindustrian perfilman yang menghasilkan film-film yang bermutu. Dilihat dengan banyaknya masyarakat yang ingin menyaksikan film-film tersebut dibioskop.

E-ticketing adalah salah satu layanan pertumbuhan yang paling cepat yang telah disediakan internet (Pew, 2002; dalam Dehbashi, 2007). Menurut Karami (2008) online eticketing merupakan sistem penjualan tiket secara online dalam hal ini adalah tiket bioskop. 


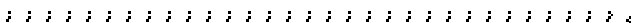

- Widya Akuntansi dan Keuangan

: Universitas Hindu Indonesia

Edisi Agustus 2020

Pelanggan dapat memperoleh informasi langsung mengenai jadwal penayangan film yang ada dibioskop. Penjualan tiket secara online memungkinkan para pelanggan untuk bisa melakukan pembelian tanpa harus mendatangi bioskop. Pelanggan dapat langsung memperoleh informasi mengenai jadwal penayangan film hingga konfigurasi tempat duduk. Semua informasi mengenai electronic ticketing disimpan secara digital dalam sistem computer milik Cineplex21. E-ticketing juga digunakan sebagai peluang untuk meminimalkan biaya atau mengoptimalkan kenyamanan pelanggan.

Adapun kendala dalam penggunaan situs MTix ini adalah seseorang yang diharapkan menggunakan situs ini tentu seseorang yang memahami dan familiar terhadap komputer atau bisa disebut dengan computer self-efficacy. Menurut Compeau \& Higgins (1995) mengungkapkan bahwa computer self-efficacy merupakan persepsi individu dari kemampuan untuk menggunakan computer dalam pemenuhan tugas, bukannya mencerminkan keterampilan komponen sederhana.

Cineplex 21 Group merupakan salah satu perusahaan pertunjukan bioskop di Indonesia yang telah mengembangkan layanan pembelian tiket berbasis internet. Hal tersebut dilakukan melalui jaringan bioskopnya yaitu Cinema XXI. Layanan pembelian tiket berbasis internet ini dikenal dengan sebutan M-Tix dan memiliki tujuan utama untuk memberikan pelayanan kenyamanan dan efisiensi kepada pelanggan ketika mereka ingin membeli tiket pertunjukan film. M-Tix adalah layanan transaksi pembelian tiket jarak jauh (remote transaction) yang menawarkan pelanggan akan pembelian tiket bioskop tanpa harus mengantri dan dapat dilakukan dimana saja jika kebutuhan akan akses layanan tersebut terpenuhi. Sejauh ini Cineplex 21 memiliki jaringan bioskop terbanyak di Bali.

Sejak diterapkan sistem pembelian tiket online berbasis MTix ini diberlakukan, pihak bioskop menaruh harapan bahwa dengan adanya sistem ini mampu memberikan kemudahan pada para konsumen membeli tiket bioskop untuk film yang diminati di berbagai bioskop yang ada di Denpasar. Dilihat dari peningkatan penggunaan internet di Indonesia terutama yang ada di Denpasar dan banyaknya situs-situs belanja online yang marak bermunculan seiring dengan perkembangan teknologi akan mampu menciptakan peluang meningkatnya kecenderungan masyarakat untuk membeli tiket bioskop secara online. Pembelian tiket bioskop secara online ini dapat menarik perhatian para konsumen karena dengan adanya MTix ini dapat lakukan pembelian tiket bioskop secara mudah diperoleh karena bisa melakukan pembelian tiket bioskop kapan saja dan dimana saja. 
Penelitian ini meneliti tentang persepsi kemudahan penggunaan, persepsi kemanfaatan karena dua variable ini merupakan bagian dari teori TAM (Technology Acceptance Model) yang dikemukakan oleh Davis pada tahun 1986. Variabel yang digunakan didalam penelitian ini mengambil dua konstruk utama yang membentuk model TAM, yaitu persepsi kemudahan dan persepsi manfaat kegunaan serta menambahakan dua konstruk diluar model ini. Adapun konstruk tersebut adalah kepercayaan dan computer selfefficacy. Penambahan dua konstruk ini untuk menilai penerimaan teknologi yang berasal dari pengalaman diri sendiri setelah menggunakan suatu sistem.

TAM berfokus pada sikap terhadap pemakaian teknologi informasi oleh pemakai dengan mengembangkan berdasarkan persepsi kemudahan penggunaan dan persepsi kegunaan dalam pemakaian teknologi informasi (Davis et al., 1989).

Menurut Sherina dan Suartana (2014) konsep TAM dilandasi oleh teori tindakan beralasan TRA (Theory of Reasoned Action), dalam TAM, penerimaan pemakai teknologi ditentukan oleh dua faktor kunci yaitu persepsi kemanfaatan adalah tingkat kepercayaan individu bahwa penggunaan teknologi akan meningkatkan kinerjanya dan persepsi kemudahan penggunaan adalah tingkat kepercayaan individu bahwa penggunaan teknologi membuatnya lebih mudah menyelesaikan masalah

Penelitian (Lim dan Ting: 2012) menyatakan bahwa perilaku konsumen dalam melakukan transaksi belanja online sebagai situs belanja online mampu menyediakan layanan yang bermanfaat bagi konsumen dan layanan yang tidak tersedia melalui belanja tradisional yang dianggap berguna oleh konsumen dan dengan demikian mengarah pada pengembangan sikap yang menguntungkan terhadap belanja online.

Banyak manfaat yang diperoleh dengan menggunakan layanan MTix, masih banyak konsimen bioskop Cinema XXI yang belum menggunakannya. Hal ini terlihat dari masih banyak nya antrian konsumen karena ingin membeli tiket menonton bioskop di loker pembelian tiket secara langsung atau di tempat. Keadaan seperti ini masih menunjukan bahwa e-ticketing dengan aplikasi MTix masih lambat dari yang diharapkan. Menurut Shen, 2003 faktor yang menyebabkan adalah kurang mudahnya penggunaan E-ticketing dalam aplikasi MTix.

Menurut penelitian Amijaya (2010) yang melakukan penelitian terhadap pengguna KlikBCA, menunjukan hasil variabel kemudahan dalam penggunaan berpengaruh positif terhadap minat ulang nasabah menggunakan internet banking. Hasil penelitian ini didukung 


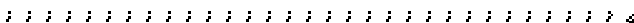

- Widya Akuntansi dan Keuangan

: Universitas Hindu Indonesia

Edisi Agustus 2020

oleh penelitian Mayasari (2011) yang juga dilakukan terhadap KlikBCA menunjukan hasil bahwa persepsi kemudahan penggunaan yang membuat nasabah memiliki sikap positif untuk menerima dan mengadopsi layanan internet banking

Menurut Lim \& Ting (2012) dalam penelitiannya menunjukan bahwa persepsi kemudahan penggunaan situs belanja online berpengaruh terhadap sikap pelanggan online shopping. Nasri dan Charfeddine (2012) menunjukan bahwa persepsi kemudahan penggunaan memiliki pengaruh yang signifikan terhadap persepsi kegunaan dan sikap terhadap internet banking. Penelitian Renny et al. (2012) menyebutkan bahwa persepsi kemudahan penggunaan secara positif mempengaruhi sikap terhadap kegunaan tiket penerbangan secara online. Berdasarkan uraian tersebut, peneliti merumuskan hipotesis sebagai berikut:

H1 : Persepsi kemudahan berpengaruh positif terhadap niat menggunakan aplikasi E-ticketing MTix Cinema XXI

Menurut penelitian Maharsi dan Yuliani (2007) yang menunjukan bahwa pengaruh persepsi manfaat terhadap intense perilaku terbukti signifikan, penelitian Mayasari dkk. (2011) juga menyebutkan bahwa persepsi manfaat (perceived usefulness) memiliki pengaruh signifikan terhadap intense perilaku (behavior intention). Menurut penelitian yang dilakukan oleh (Lee \& Wan, 2010) persepsi kemanfaatan merupakan tingkatan kepercayaan seseorang terhadap penggunaan suatu subyek tertentu yang dapat memberikan manfaat bagi orang yang menggunakannya dalam hal ini subyek yang akan dimaksudkan adalah niat dalam menggunakan e-ticketing pada transJakarta.

Penelitian Lim \& Ting (2012) menunjukan bahwa persepsi kegunaan situs belanja online berpengaruh terhadap sikap pelanggan online shopping. Sementara itu, penelitian yang Nasri dan Charfeddine (2012) juga menjelaskan bahwa persepsi kegunaan secara signifikan dan positif mempengaruhi sikap terhadap internet banking. Berdasarkan uraian tersebut, peneliti merumuskan hipotesis sebagai berikut:

H2 : Persepsi manfaat kegunaan berpengaruh positif terhadap niat menggunakan aplikasi E-ticketing MTix Cinema XXI

Menurut penelitian Sulaiman et. al. (2008) mengenai penggunaan trend e-ticketing di Malaysia menunjukan bahwa faktor kepercayaan berpengaruh terhadap minat pengguna dalam membeli tiket online, hasil penelitian tersebut konsisten dengan hasil penelitian Duraisamy (2008) yang menunjukan bahwa kepercayaan berpengaruh positif terhadap minat 
ijizizis

: Widya Akuntansi dan Keuangan

: Universitas Hindu Indonesia

Edisi Agustus 2020

penggunaan sistem e-ticketing. Kesharwani (2008) dimana penelitiannya pada penggunaan internet banking yang mendapatkan hasil serupa yaitu kepercayaan berpengaruh positif terhadap minat penggunaan internet. Sementara itu, Renny et al. (2012) dalam hasil penelitian nya menjelaskan bahwa kepercayaan secara positif mempengaruhi sikap terhadap kegunaan tiket penerbangan secara online. Berdasarkan uraian tersebut, peneliti merumuskan hipotesis alternative sebagai berikut:

H3 : Kepercayaan berpengaruh positif terhadap niat menggunakan aplikasi E-ticketing MTix Cinema XXI

Menurut penelitian Yusoff (2012) menunjukan bahwa penggunaan antarmuka teknologi dan alat-alat disitus online yang penting dalam memprediksi sikap terhadap belanja online. Penelitian yang dilakukan oleh Jang et al. (2011) akan tetapi penelitian ini tidak memiliki hasil yang positif terhadap sikap dalam membeli. Irmadhani (2012) menunjukan bahwa Computer Self Efficacy berpengaruh positif dan signifikan terhadap penggunaan online Banking. Menurut Compeau et al. sebagaimana dikutip Hwa $\mathrm{Hu}$ et al, computer self efficacy mengacu penilaian pada individu atas kemampuannya untuk menggunakan computer. Ditemukan e-learning self efficacy berperan pening dalam mempengaruhi sikap terhadap e-learning dan niat perilaku untuk menggunakan e-learning. Berdasarkan uraian tersebut, peneliti merumuskan hipotesis sebagai berikut:

H4 : Computer self-efficacy berpengaruh positif terhadap niat menggunakan aplikasi E-ticketing MTix Cinema XXI

\section{METODE PENELITIAN}

Penelitian ini dilakukan di selurh gerai Cinema XXI, alasan pemilihan lokasi karena aplikasi tiket bioskop elektronik pertama kali dikembangkan oleh Cinema XXI, pemilihan sampel dalam penelitian ini menggunakan teknik purposive sampling yaitu pengambilan sampel dengan menggunakan kriteria-kriteria tertentu yang diperlukan bagi penelitiannya. Adapun kriteria-kriteria tersebut antara lain: a) Memiliki akun M-Tix yang ada di Cinema XXI;b) Pernah menggunakan M-Tix dalam kurun waktu minimal 6 bulan terakhir. Jenis data yang digunakan dalam penelitian ini adalah data kuantitatif dan sumber data yang digunakan dalam penelitian ini adalah data primer. Teknik pengumpulan data dalam penelitian ini adalah dengan menyebarkan kuisioner. 


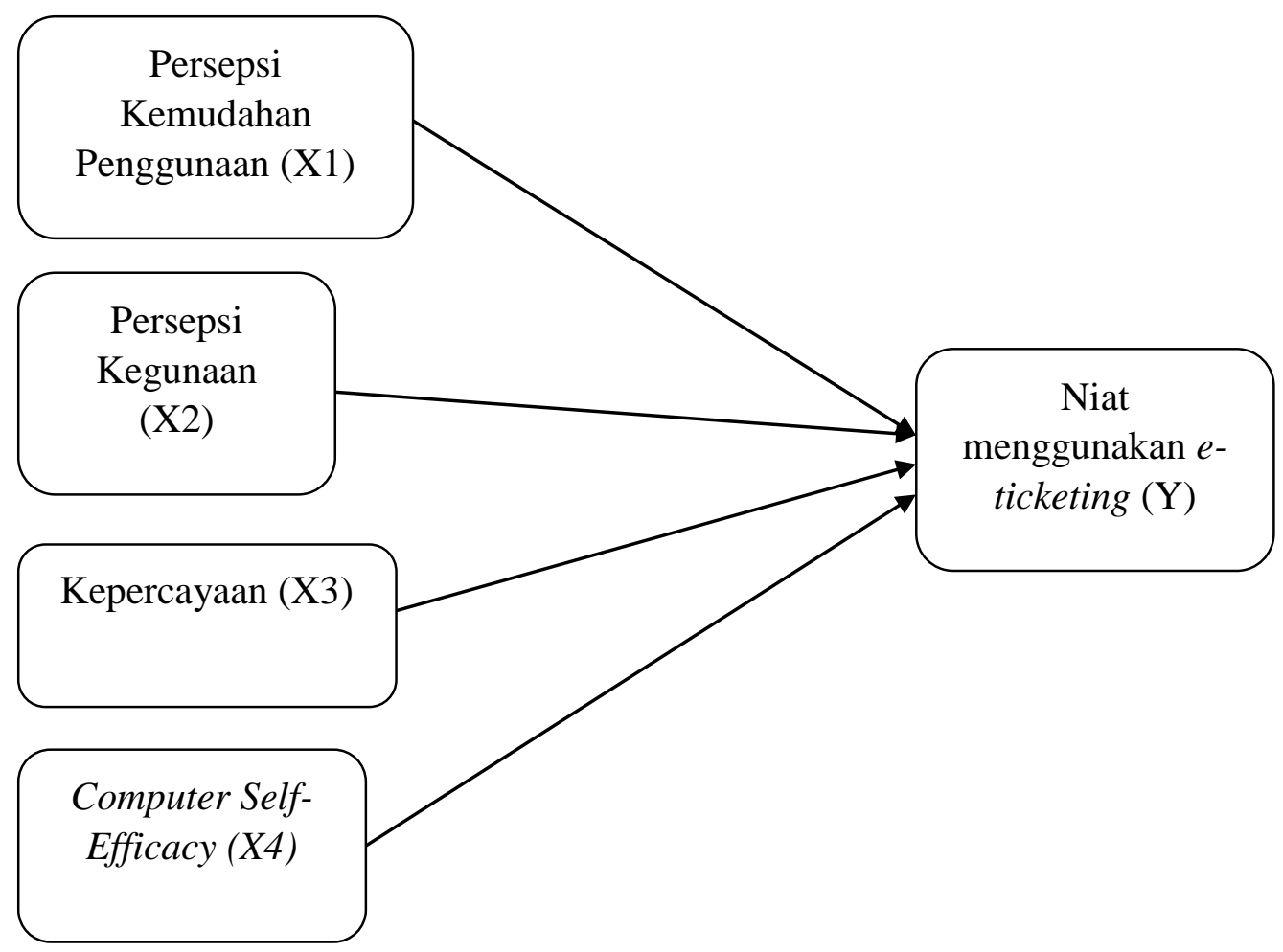

Gambar 1. Kerangka Penelitian

\section{HASIL DAN PEMBAHASAN}

\section{Karakteristik Responden}

Tabel 1 : Karakteristik Responden

\begin{tabular}{|l|c|c|c|}
\hline & Karakteristik & Jumlah & Persentase(\%) \\
\hline a & Jenis kelamin & & \\
\hline & Laki-laki & 50 & 66,7 \\
\hline & Perempuan & 20 & 26,7 \\
\hline b & Pendidikan & & \\
\hline & SMA & 10 & 13,3 \\
\hline & D3 & 25 & 33,3 \\
\hline & S1 & 40 & 53,3 \\
\hline c & Umur & & \\
\hline & $20-25 \mathrm{Th}$ & 20 & 13,3 \\
\hline & $>25-35 \mathrm{Th}$ & 45 & 26,7 \\
\hline & $>35 \mathrm{Th}$ & 75 & 60,0 \\
\hline & Jumlah & & 100 \\
\hline
\end{tabular}

Sumber : Data Diolah

Berdasarkan tabel diatas menunjukkan bahwa sebagian besar responden dalam penelitian ini adalah berjenis kelamin laki-laki sebanyak $(66,7 \%)$, berdasarkan tingkat 
pendidikan sebagian besar tingkat sarjana $(53,3 \%)$. Berdasarkan umur diperoleh $>35$ tahun sebanyak $60 \%$.

\section{Uji Validitas}

Pengujian validitas dan reliabilitas terhadap instrumen - instrumen di dalam kuesioner sangatlah penting dilakukan untuk memperoleh hasil penelitian yang valid dan reliabel. Dengan demikian instrumen yang valid dan reliabel merupakan syarat mutlak untuk mendapatkan hasil penelitian yang valid dan reliabel. Pengujian validitas disini dilakukan pada 30 responden dengan taraf signifikan 5\%. Sehingga diperoleh hasilnya sebagai berikut:

Tabel 2 : Karakteristik Responden

\begin{tabular}{|c|l|c|c|}
\hline No & Item Pertanyaan & Koefisien Korelasi & Keterangan \\
\hline 1 & X1.1 & 0,715 & Valid \\
\hline 2 & X1.2 & 0,806 & Valid \\
\hline 3 & X1.3 & 0,663 & Valid \\
\hline 4 & X1.4 & 0,806 & Valid \\
\hline 5 & X1.5 & 0,867 & Valid \\
\hline 6 & X2.1 & 0,890 & Valid \\
\hline 7 & X2.2 & 0,934 & Valid \\
\hline 8 & X2.3 & 0,939 & Valid \\
\hline 9 & X2.4 & 0,939 & Valid \\
\hline 10 & X3.1 & 0,890 & Valid \\
\hline 11 & X3.2 & 0,841 & Valid \\
\hline 12 & X3.3 & 0,903 & Valid \\
\hline 13 & X3.4 & 0,934 & Valid \\
\hline 14 & X4.1 & 0,887 & Valid \\
\hline 15 & X4.2 & 0,944 & Valid \\
\hline 16 & X4.3 & 0,840 & Valid \\
\hline 17 & Y1 & 0,642 & Valid \\
\hline 18 & Y2 & 0,811 & Valid \\
\hline 19 & Y3 & 0,841 & Valid \\
\hline 20 & Y4 & 0,841 & Valid \\
\hline
\end{tabular}

Sumber : Data Diolah

Nilai $r$ hitung pada tabel di atas menunjukkan bahwa semua nilai $r$ hitung diatas lebih besar dari 0,3. Dengan demikian seluruh instrumen penelitian yang digunakan adalah valid selanjutnya instrument-instrument tersebut dapat digunakan untuk menganalisis statistik lebih lanjut.

\section{Uji Reliabilitas}

Menurut Sugiyono (2010) mengatakan bahwa variabel dikatakan reliabel jika memberikan nilai alpha cronbach $>0,60$. 


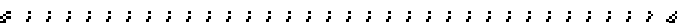

: Widya Akuntansi dan Keuangan

: Universitas Hindu Indonesia

Edisi Agustus 2020

Tabel 3 : Karakteristik Responden

\begin{tabular}{|c|l|c|c|}
\hline No & \multicolumn{1}{|c|}{ Variabel } & Koefisien Korelasi & Keterangan \\
\hline 1 & Persepsi kemudahan & 0,909 & Reliabel \\
\hline 2 & Persepsi kegunaan & 0,970 & Reliabel \\
\hline 3 & Kepercayaan & 0,954 & Reliabel \\
\hline 4 & $\begin{array}{l}\text { Computer self } \\
\text { efficacy }\end{array}$ & 0,947 & Reliabel \\
\hline 5 & Niat menggunakan & 0,902 & Reliabel \\
\hline
\end{tabular}

Sumber : Data Diolah

Semua instrumen memiliki nilai alpha cronbach lebih dari 0,6 sehingga dapat disimpulkan bahwa semua variabel tersebut reliabel.

\section{Uji Asumsi Klasik}

1. Uji Normalitas

Uji normalitas bertujuan untuk melihat data yang digunakan dalam penelitian telah berdistribusi normal. Untuk mengetahui apakah residual berdistribusi normal atau tidak salah satunya dengan melakukan uji statistik non parametrik Kolmogorov-Smirnov (K-S).

Tabel 4. Nilai Asymp. Sig. (2-tailed) untuk Uji Normalitas

One-Sample Kolmogorov-Smirnov Test

\begin{tabular}{|ll|r|}
\hline & & $\begin{array}{r}\text { Unstandardiz } \\
\text { ed Residual }\end{array}$ \\
\hline N & & 75 \\
Normal Parameters a,b & Mean &, 0000000 \\
Most Extreme & Std. Deviation &, 33198398 \\
Differences & Absolute &, 108 \\
& Positive &, 108 \\
Kolmogorov-Smirnov Z & Negative &,- 084 \\
Asymp. Sig. (2-tailed) & &, 934 \\
\hline
\end{tabular}

a. Test distribution is Normal.

b. Calculated from data.

Berdasarkan output SPSS diperoleh nilai Asymp. Sig. (2-tailed) 0,347 yang lebih besar dari 0,05 . Hal itu berarti residual data berdistribusi normal.

2. Uji Multikolinearitas 
Pengujian untuk mendeteksi gejala multikolinearitas dilakukan dengan melihat nilai Variance Inflation Factor (VIF). Berdasarkan hasil penelitian menunjukkan bahwa nilai VIF yang dihasilkan dalam SPSS tidak terjadi multikolenearitas. Kesimpulan ini ditarik dari hasil yang terlihat pada Tabel 4.3 , dimana nilai VIF $<10$ dan nilai tolerance lebih dari 0,10 untuk masing-masing variabel bebas, ini berarti tidak terjadi multikolinearitas.

\section{Tabel 5 Nilai Tolerance dan VIF}

\section{Coefficients}

\begin{tabular}{|ll|r|r|}
\hline \multirow{2}{*}{ Model } & \multicolumn{2}{|c|}{ Collinearity Statistics } \\
\cline { 3 - 4 } & & Tolerance & \multicolumn{1}{c|}{ VIF } \\
\hline 1 & Kemudahan &, 572 & 1,750 \\
& Kegunaan &, 655 & 1,526 \\
& Kepercayaan &, 742 & 1,347 \\
& Self efficacy &, 867 & 1,153 \\
\hline
\end{tabular}

a. Dependent Variable: Niat menggunakan e-ticketing

Berdasarkan output SPSS diperoleh nilai tolerance berturut-turut sebesar 0,572 ; 0,$655 ; 0,742,0,867$ yang kesemuanya lebih besar dari 10 persen $(0,10)$, dan nilai VIF sebesar 1,$750 ; 1,526 ; 1,347 ; 1,153$ yang kesemuanya lebih kecil dari 10 . Hal ini berarti model regresi tersebut lolos uji multikolinearitas.

\section{Uji Heteroskedastisitas}

Cara untuk mendeteksi ada tidaknya heterokedastisitas dapat diketahui dengan menggunakan uji statistik Glejser. Model regresi tidak mengandung adanya heteroskedastisitas bila nilai signifikansi variabel bebasnya terhadap nilai absolute residual statistic di atas $\alpha=0,05$.

Tabel 6 Uji Heteroskedasitas

Coefficients ${ }^{a}$

\begin{tabular}{|ll|r|r|r|r|r|}
\hline \multirow{2}{*}{ Model } & \multicolumn{2}{|c|}{$\begin{array}{c}\text { Unstandardized } \\
\text { Coefficients }\end{array}$} & \multicolumn{2}{c|}{$\begin{array}{c}\text { Standardized } \\
\text { Coefficients }\end{array}$} & \\
\cline { 3 - 5 } & & \multicolumn{1}{|c|}{$\mathrm{B}$} & Std. Error & \multicolumn{1}{c|}{ Beta } & \multicolumn{1}{c|}{$\mathrm{t}$} & \multicolumn{1}{c|}{ Sig. } \\
\hline 1 & (Constant) &, 478 &, 573 & &, 834 &, 407 \\
& Kemudahan &,- 002 &, 017 &,- 020 &,- 135 &, 893 \\
& Kegunaan &,- 041 &, 181 &,- 308 &,- 225 &, 727 \\
& Kepercayaan &,- 002 &, 015 &,- 020 &,- 155 &, 878 \\
& Self efficacy &, 031 &, 017 &, 217 & 1,827 &, 072 \\
\hline
\end{tabular}

a. Dependent Variable: Abres

Hasil uji Gletser diperoleh nilai signifikansi variabel kemudahan sebesar 0,893, variabel kegunaan 0,727 , variabel kepercayaan sebesar 0,878 , dan variabel self eficacy 
sebesar 0,072 semua nilai sig pada ketiga variabel bebas lebih besar dari 0,05. Hal ini berarti model regresi tersebut tidak mengandung gejala heteroskedastisitas.

\section{Uji Analisis Regresi Berganda}

Model yang digunakan dalam menganalisa pengaruh persepsi kemudahan, persepsi kegunaan, kepercayaan, compter self efficacy terhadap niat menggunakan e-ticketing adalah model regresi linier berganda dengan bantuan SPSS versi 22.0 serta diuji dengan tingkat signifikansi 5\%. Dalam model regresi linier berganda ini, persepsi kemudahan (X1), persepsi kegunaan (X2), kepercayaan (X3), dan computer self efficacy (X4) digunakan sebagai variabel bebas, sedangkan niat menggunakan e-ticketing (Y) sebagai variabel terikat.

Tabel 7 Hasil Regresi Linear Berganda

Coefficients

\begin{tabular}{|c|c|c|c|c|c|c|}
\hline \multirow{2}{*}{\multicolumn{2}{|c|}{ Model }} & \multicolumn{2}{|c|}{$\begin{array}{c}\text { Unstandardized } \\
\text { Coefficients }\end{array}$} & \multirow{2}{*}{$\begin{array}{c}\begin{array}{c}\text { Standardized } \\
\text { Coefficients }\end{array} \\
\text { Beta }\end{array}$} & \multirow[b]{2}{*}{$t$} & \multirow[b]{2}{*}{ Sig. } \\
\hline & & $\mathrm{B}$ & Std. Error & & & \\
\hline \multirow[t]{5}{*}{1} & (Constant) & 2,632 & 1,014 & & 2,595 &, 012 \\
\hline & Kemudahan & ,098 & , 030 & ,242 & 3,312 & ,001 \\
\hline & Kegunaan & ,250 & ,032 &, 532 & 7,798 & ,000 \\
\hline & Kepercayaan & ,363 & , 027 & ,866 & 13,511 & ,000 \\
\hline & Self efficacy & ,182 & ,030 & ,360 & 6,061 & ,000 \\
\hline
\end{tabular}

a. Dependent Variable: Niat menggunakan e-ticketing

1. Koefisien konstanta sebesar 2,632, artinya bila variabel persepsi kemudahan(X1), persepsi kegunaan (X2), kepercayaan (X3) dan self efficacy (X4) konstan pada angka 0 (nol) maka niat menggunakan e-ticketing (Y) sebesar 2,632.

2. Nilai koefisien regresi persepsi kemudahan $(X 1)=0,098$, secara statistik menunjukkan bahwa jika persepsi kemudahan ditingkatkan sebesar 1 satuan, maka niat menggunakan e-ticketing meningkat sebesar 0,098 dengan asumsi variabel lain konstan.

3. Nilai koefisien regresi persepsi kegunaan $(X 2)=0,250$, secara statistik menunjukkan bahwa, jika persepsi kegunaan ditingkatkan sebesar 1 satuan, maka niat menggunakan e-ticketing meningkat sebesar 0,250 dengan asumsi variabel lain konstan.

4. Nilai koefisien regresi kepercayaan $(X 3)=0,363$, secara statistik menunjukkan bahwa, jika kepercayaan ditingkatkan sebesar 1 satuan, maka niat menggunakan eticketing meningkat sebesar 0,363 dengan asumsi variabel lain konstan. 
5. Nilai koefisien regresi computer self efficacy $(X 4)=0,182$, secara statistik menunjukkan bahwa, jika computer self eficacy ditingkatkan sebesar 1 satuan, maka niat menggunakan e-ticketing meningkat sebesar 0,182 dengan asumsi variabel lain konstan.

\section{Uji Goodness of Fit}

Uji Signifikansi Simultan F

Tabel 8. Hasil Uji Simultan F

ANOVA

\begin{tabular}{|c|c|c|c|c|c|c|}
\hline Model & & $\begin{array}{l}\text { Sum of } \\
\text { Squares }\end{array}$ & df & Mean Square & $\mathrm{F}$ & Sig. \\
\hline \multirow[t]{3}{*}{1} & Regression & 30,031 & 4 & 7,508 & 64,438 &, $000^{a}$ \\
\hline & Residual & 8,156 & 70 & , 117 & & \\
\hline & Total & 38,187 & 74 & & & \\
\hline
\end{tabular}

a. Predictors: (Constant), Self efficacy, Kegunaan, Kepercayaan, Kemudahan

b. Dependent Variable: Niat menggunakan e-ticketing

Sesuai hasil perhitungan diperoleh Fhitung $=64,438$, nilai sig 0,00 , pada $\operatorname{tar} \alpha \alpha=5$ $\%$ secara simultan persepsi kemudahan, persepsi kegunaan, kepercayaan dan self efficacy berpengaruh signifikan terhadap niat menggunakan e-ticketing.

Analisis Determinasi Berganda

Analisis ini digunakan untuk mengetahui besarnya kontribusi persepsi kemudahan (X1), persepsi kegunaan (X2), kepercayaan (X3) dan self efficacy (X4) terhadap niat menggunakan e-ticketing (Y). Yang dinyatakan dalam persentase, dengan rumus $\mathrm{D}=\mathrm{R} 2 \mathrm{x}$ $100 \%$.

Tabel 9. Koefiien Determinasi

Model Summary

\begin{tabular}{|l|r|r|r|r|}
\hline Model & $\mathrm{R}$ & R Square & $\begin{array}{c}\text { Adjusted } \\
\text { R Square }\end{array}$ & $\begin{array}{r}\text { Std. Error of } \\
\text { the Estimate }\end{array}$ \\
\hline 1 &, $887^{\mathrm{a}}$ &, 786 &, 774 &, 34134 \\
\hline
\end{tabular}

a. Predictors: (Constant), Self efficacy, Kegunaan, Kepercayaan, Kemudahan

b. Dependent Variable: Niat menggunakan e-ticketing

Berdasarkan Tabel 4.9 diperoleh besarnya koefisien determinasi sebesar 0,786 atau 78,6\%. Ini menunjukkan pengaruh persepsi kemudahan (X1), persepsi kegunaan (X2), kepercayaan (X3) dan self efficacy (X4) memberikan kontribusi naik turunnya niat 


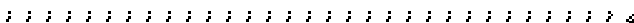

: Widya Akuntansi dan Keuangan

: Universitas Hindu Indonesia

Edisi Agustus 2020

menggunakan e-ticketing sebesar 78,6\% dan 21,4\% disebabkan oleh faktor lain yang tidak dibahas dalam penelitian ini.

Uji Secara Parsial (Uji t)

1. Pengaruh persepsi kemudahan secara parsial terhadap niat menggunakan e-ticketing

Pengujian signifikansi pengaruh persepsi kemudahan terhadap niat menggunakan eticketing secara parsial dilakukan dengan melakukan uji t, yaitu dengan membandingkan nilai signifikansi t dengan $\alpha(0,05)$. Variabel persepsi kemudahan dengan nilai sig 0,001 $<\alpha(0,05)$ yang berarti penolakan H0 sehingga H1 diterima. Yang berarti persepsi kemudahan berpengaruh positif dan signifikan terhadap niat menggunakan e-ticketing.

2. Pengaruh persepsi kegunaan secara parsial terhadap niat menggunakan e-ticketing Pengujian signifikansi pengaruh persepsi kegunaan terhadap niat menggunakan eticketing secara parsial dilakukan dengan melakukan uji t, yaitu dengan membandingkan nilai signifikansi t dengan $\alpha(0,05)$. Variabel persepsi kegunaan dengan nilai sig $0,000<$ $\alpha(0,05)$ yang berarti penolakan $\mathrm{H} 0$ sehingga $\mathrm{H} 2$ diterima. Yang berarti persepsi kegunaan berpengaruh positif dan signifikan terhadap niat menggunakan e-ticketing.

3. Pengaruh kepercayaan secara parsial terhadap niat menggunakan e-ticketing

Pengujian signifikansi pengaruh kepercayaan terhadap niat menggunakan e-ticketing secara parsial dilakukan dengan melakukan uji t, yaitu dengan membandingkan nilai signifikansi t dengan $\alpha(0,05)$. Variabel kepercayaan dengan nilai sig $0,000<\alpha(0,05)$ yang berarti penolakan $\mathrm{H} 0$ sehingga $\mathrm{H} 3$ diterima. Yang berarti kepercayaan berpengaruh positif dan signifikan terhadap niat menggunakan e-ticketing.

4. Pengaruh computer self efficacy secara parsial terhadap niat menggunakan e-ticketing Pengujian signifikansi pengaruh computer self efficacy terhadap niat menggunakan eticketing secara parsial dilakukan dengan melakukan uji t, yaitu dengan membandingkan nilai signifikansi t dengan $\alpha(0,05)$. Variabel computer self efficacy dengan nilai sig 0,000 $<\alpha(0,05)$ yang berarti penolakan $\mathrm{H} 0$ sehingga $\mathrm{H} 4$ diterima. Yang berarti computer self efficacy berpengaruh positif dan signifikan terhadap niat menggunakan e-ticketing.

Tabel 10. Ringkasan Uji Hipotesis

\begin{tabular}{|c|c|c|}
\hline Hipotesis & Nilai Sig & Keterangan \\
\hline H1 & 0,001 & Signifikan \\
\hline H2 & 0,000 & Signifikan \\
\hline H3 & 0,000 & Signifikan \\
\hline H4 & 0,000 & Signifikan \\
\hline
\end{tabular}




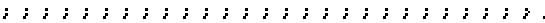

: Widya Akuntansi dan Keuangan

: Universitas Hindu Indonesia

Edisi Agustus 2020

\section{PEMBAHASAN}

Pengaruh Persepsi Kemudahan Secara Parsial Terhadap Niat Menggunakan ETicketing

Hasil penelitian menunjukkan secara empiris pengujian signifikansi pengaruh persepsi kemudahan terhadap niat menggunakan e-ticketing secara parsial dilakukan dengan melakukan uji t, yaitu dengan membandingkan nilai signifikansi t dengan $\alpha(0,05)$. Variabel persepsi kemudahan dengan nilai sig $0,001<\alpha(0,05)$ yang berarti penolakan H0 sehingga $\mathrm{H} 1$ diterima. Yang berarti persepsi kemudahan berpengaruh positif dan signifikan terhadap niat menggunakan e-ticketing. Dengan demikian dapat dikatakan bahwa semakin tinggi persepsi kemudahan maka konsumen semakin berniat menggunakan e-ticketing, begitu sebaliknya semakin rendah persepsi kemudahan maka konsumen semakin kurang berniat menggunakan e-ticketing.

Menurut penelitian Amijaya (2010) yang melakukan penelitian terhadap pengguna KlikBCA, menunjukan hasil variabel kemudahan dalam penggunaan berpengaruh positif terhadap minat ulang nasabah menggunakan internet banking. Hasil penelitian ini didukung oleh penelitian Mayasari (2011) yang juga dilakukan terhadap KlikBCA menunjukan hasil bahwa persepsi kemudahan penggunaan yang membuat nasabah memiliki sikap positif untuk menerima dan mengadopsi layanan internet banking

Menurut Lim \& Ting (2012) dalam penelitiannya menunjukan bahwa persepsi kemudahan penggunaan situs belanja online berpengaruh terhadap sikap pelanggan online shopping. Nasri dan Charfeddine (2012) menunjukan bahwa persepsi kemudahan penggunaan memiliki pengaruh yang signifikan terhadap persepsi kegunaan dan sikap terhadap internet banking. Penelitian Renny et al. (2012) menyebutkan bahwa persepsi kemudahan penggunaan secara positif mempengaruhi sikap terhadap kegunaan tiket penerbangan secara online.

\section{Pengaruh Persepsi Kegunaan Secara Parsial Terhadap Niat Menggunakan E-}

\section{Ticketing}

Pengujian signifikansi pengaruh persepsi kegunaan terhadap niat menggunakan eticketing secara parsial dilakukan dengan melakukan uji t, yaitu dengan membandingkan nilai signifikansi t dengan $\alpha(0,05)$. Variabel persepsi kegunaan dengan nilai sig $0,000<$ $\alpha(0,05)$ yang berarti penolakan $\mathrm{H} 0$ sehingga $\mathrm{H} 2$ diterima. Yang berarti persepsi kegunaan berpengaruh positif dan signifikan terhadap niat menggunakan e-ticketing. 
ijisidis

: Widya Akuntansi dan Keuangan

: Universitas Hindu Indonesia

Edisi Agustus 2020

Dengan demikian dapat dikatakan bahwa semakin tinggi persepsi kegunaan maka konsumen semakin berniat menggunakan e-ticketing, begitu sebaliknya semakin rendah persepsi kegunaan maka konsumen semakin kurang berniat menggunakan eticketing.Menurut penelitian Maharsi dan Yuliani (2007) yang menunjukan bahwa pengaruh persepsi manfaat terhadap intense perilaku terbukti signifikan, penelitian Mayasari dkk. (2011) juga menyebutkan bahwa persepsi manfaat (perceived usefulness) memiliki pengaruh signifikan terhadap intense perilaku (behavior intention). Menurut penelitian yang dilakukan oleh (Lee \& Wan, 2010) persepsi kemanfaatan merupakan tingkatan kepercayaan seseorang terhadap penggunaan suatu subyek tertentu yang dapat memberikan manfaat bagi orang yang menggunakannya dalam hal ini subyek yang akan dimaksudkan adalah niat dalam menggunakan e-ticketing pada transJakarta. Penelitian Lim \& Ting (2012) menunjukan bahwa persepsi kegunaan situs belanja online berpengaruh terhadap sikap pelanggan online shopping. Sementara itu, penelitian yang Nasri dan Charfeddine (2012) juga menjelaskan bahwa persepsi kegunaan secara signifikan dan positif mempengaruhi sikap terhadap internet banking

\section{Pengaruh Kepercayaan Secara Parsial Terhadap Niat Menggunakan E-Ticketing}

Pengujian signifikansi pengaruh kepercayaan terhadap niat menggunakan e-ticketing secara parsial dilakukan dengan melakukan uji t, yaitu dengan membandingkan nilai signifikansi t dengan $\alpha(0,05)$. Variabel kepercayaan dengan nilai sig $0,000<\alpha(0,05)$ yang berarti penolakan $\mathrm{H} 0$ sehingga $\mathrm{H} 3$ diterima. Yang berarti kepercayaan berpengaruh positif dan signifikan terhadap niat menggunakan e-ticketing. Dengan demikian dapat dikatakan bahwa semakin tinggi kepercayaan maka konsumen semakin berniat menggunakan e-ticketing, begitu sebaliknya semakin rendah kepercayaan maka konsumen semakin kurang berniat menggunakan e-ticketing.

Menurut penelitian Sulaiman et. al. (2008) mengenai penggunaan trend e-ticketing di Malaysia menunjukan bahwa faktor kepercayaan berpengaruh terhadap minat pengguna dalam membeli tiket online, hasil penelitian tersebut konsisten dengan hasil penelitian Duraisamy (2008) yang menunjukan bahwa kepercayaan berpengaruh positif terhadap minat penggunaan sistem e-ticketing. Kesharwani (2008) dimana penelitiannya pada penggunaan internet banking yang mendapatkan hasil serupa yaitu kepercayaan berpengaruh positif terhadap minat penggunaan internet. Sementara itu, Renny et al. 
ijisidis

: Widya Akuntansi dan Keuangan

: Universitas Hindu Indonesia

Edisi Agustus 2020

(2012) dalam hasil penelitian nya menjelaskan bahwa kepercayaan secara positif mempengaruhi sikap terhadap kegunaan tiket penerbangan secara online

\section{Pengaruh Computer Self Efficacy Secara Parsial Terhadap Niat Menggunakan E- Ticketing}

Pengujian signifikansi pengaruh computer self efficacy terhadap niat menggunakan e-ticketing secara parsial dilakukan dengan melakukan uji t, yaitu dengan membandingkan nilai signifikansi t dengan $\alpha(0,05)$. Variabel computer self efficacy dengan nilai sig $0,000<\alpha(0,05)$ yang berarti penolakan $\mathrm{H} 0$ sehingga $\mathrm{H} 4$ diterima. Yang berarti computer self efficacy berpengaruh positif dan signifikan terhadap niat menggunakan e-ticketing. Dengan demikian dapat dikatakan bahwa semakin tinggi computer self efficacy maka konsumen semakin berniat menggunakan e-ticketing, begitu sebaliknya semakin rendah computer self efficacy maka konsumen semakin kurang berniat menggunakan e-ticketing.

Menurut penelitian Yusoff (2012) menunjukan bahwa penggunaan antarmuka teknologi dan alat-alat disitus online yang penting dalam memprediksi sikap terhadap belanja online. Penelitian yang dilakukan oleh Jang et al. (2011) akan tetapi penelitian ini tidak memiliki hasil yang positif terhadap sikap dalam membeli. Irmadhani (2012) menunjukan bahwa computer self efficacy berpengaruh positif dan signifikan terhadap penggunaan online Banking. Menurut Compeau et al. sebagaimana dikutip Hwa $\mathrm{Hu}$ et al, computer self efficacy mengacu penilaian pada individu atas kemampuannya untuk menggunakan computer. Ditemukan e-learning self efficacy berperan pening dalam mempengaruhi sikap terhadap e-learning dan niat perilaku untuk menggunakan elearning

\section{SIMPULAN DAN SARAN}

Hasil analisis menunjukan adanya pengaruh positif dan signifikan secara parsial persepsi kemudahan berpengaruh positif dan signifikan terhadap niat menggunakan eticketing, persepsi kegunaan berpengaruh positif dan signifikan terhadap niat menggunakan e-ticketing, kepercayaan berpengaruh positif dan signifikan terhadap niat menggunakan eticketing, computer self efficacy berpengaruh positif dan signifikan terhadap niat menggunakan e-ticketing. 
Untuk penelitian selanjutnya untuk memperluas objek penelitian terutama dalam eticketing, karena dalam perkembangannya e-ticketing tidak hanya diterapkan dibioskop tetapi juga di sektor transportasi.

\section{DAFTAR PUSTAKA}

Adamson, I., \& Shine,J. (2003). Extending the New Technology Acceptance Model to Measure the End User Information Systems Satisfaction in a Mandatory Environment: A Bank's Treasury, Technology Analysis \& Strategic Management. Vol. 15 No. 4: pp 441-455.

Adam, D.A., Nelson, R. R., \& Todd, P. A. 1992. Perceived Usefulness, Ease of use, and Usage of Information Technology: A Replication. MIS Quarterly, 16(2), 227-247

Amijaya, Gilang Rizky. 2010. Pengaruh Persepsi Teknologi Informasi, Kemudahan, Resiko, dan Fitur Layanan terhadap Minat Ulang Nasabah Bank dalam Menggunakan Internet Banking (Studi pada Nasabah Bank BCA). Skripsi Fakultas Ekonomi Universitas Diponegoro Semarang.

Compeau, D.R., \& Higgins, C.A. 1995. Computer selfeffiecancy: Development of a measure and initial test. MIS Quarterly, 19(2): 189-221.

Dehbashi, Shima. 2007. Factors Affecting on Iranian Customes Acceptance Toward ETicketing Provided by Airlines. Thesis Lulea University of Technology.

Davis, F.D. 1989. Perceived Usefulness, Perceived Ease of Use, and User Acceptance of Information Technology. MIS Quarterly. Vol. 13 No. 5: pp319-339.

Doni Jomes, 2011 Pengenalan Sistem Tiket Bioskop Online: Penelitian Andi. Yogyakarta.

Duraisamy, Thiagarajan. 2008. Now Everyone Can Trust Online An Analysis On How Malaysians View Online Flight Booking.

Ghozali, Imam. 2013. Aplikasi Analisis Multivariate Dengan Program IBM SPSS 21. Semarang: Badan penerbit Universitas Diponegoro.

Irmadhani. 2012. Pengaruh Persepsi Kebermanfaatan, Persepsi Kemudahan Penggunaan dan Computer Self Efficacy, terhadap Penggunaan online banking pada Mahasiswa S1 Fakultas Ekonomi Universitas Negeri Yogyakarta. Skripsi. Universitas Negeri Yogyakarta.

Jang, H. Y. \& Mi, J. N. 2011. "Customer Acceptance of IPTV Service Quality". International Journal of Information Management. 582-592.

Karami, Mitra. 2008. Factor Influencing Adoption Online Ticketing. Lulela University of Technology. Master Thesis, 2006:45 ISBN:1653-0187

Kesharwani, Ankit and Shailendra Singh Bisht. 2012. The Impact of Trust and Perceived Risk on the Internet Banking Adoption in India. International Journal of Bank Marketing. Vol. 30 (4) pp:303-322.

Kusuma, W. 2009. Mengenal Penelitian Tindakan Kelas. Jakarta: Indeks. 
Lee,C. B., \& Wan, G. 2010. Partial Least Square: Konsep, Teknik dan Aplikasi. Semarang: Badan Penerbit Universitas Diponogoro.

Lim,W. M. \& Ting D.H. 2012. "E-shopping: an Analysis of the Technology Acceptance Model" Canadian Center of Science and Education. Vol. 6, No. 4; April 2012

Mayasri, Feronica, Elisabeth Penti Kurniawati, dan Paskah Ika Nugroho. 2011. Anteseden dan Konsekuen Sikap Nasabah dalam Menggunakan Internet Banking dengan Menggunakan Kerangka Techology Acceptance Model (TAM) (Survey pada Pengguna KlikBCA). Salatiga: Seminar Nasional Teknologi Informasi dan Komunikasi Terapan. ISBN 979-26-0255-0.

Mahasri, Sri dan Yuliani, M. 2007. Faktor-Faktor yang Mempengaruhi Minat Nasabah Menggunakan Internet Banking dengan Menggunakan Kerangka Technology Acceptance Model. Jurnal Akuntansi dan Keuangan. Vol 9 (1) pp: 18-28.

Ng-Kruelle, G. dan P. A. Swatman. 2006. E-Ticketing Strategy and Implementation in an Open Access System: The case of Deutsche Bahn

Nicholas, Bienz (2008).”Electronic Ticketing:Electronic Business Course Fribourg. Project Paper

Nasri, Wadie, and Charfeddine, Lanouar. 2012. Journal of High Technology Management Research. Factors Affecting The Adoption of Internet Banking in Tunisia: An Integration Theory of Acceptance Model and Theory of Planned Behavior

Renny., Guritno, Suryo., Siringoringo, Hotniar. 2012. Perceived Usefulness, Ease of use, and Attitude Towards Online Shopping Usefulness Towards Online Airlines Ticket Purchase

Rustiana, 2004. "Computer Selft Efficacy (CSE) Mahasiswa Akuntansi Dalam Penggunaan Teknologi Informasi: Tinjauan Perspektif Gender”, Jurnal Ekonomi Akuntansi, Vol 17, No. 1, Maret.

Shen. 2003. "Building Customer Trust in Mobile Commerce." Communication of The ACM (Communication of The ACM) 91-94.

Sujarweni, Wiratna. 2015. SPSS Untuk Penelitian. Yogyakarta: Pustaka Baru Press Sulaiman, Ainin., Josephine Ng., and Suhana Mohezar. 2008. E-Ticketing as a New Way of Buying Tickets: Malaysian Perceptions. Vol. 17 (2) pp: 149-157.

Sugiyono. 2014. Metode Kuantitatif Kuantitaif dan R\&D. Bandung: Alfabeta.

Sri Maharsi dan Yuliani Mulyadi, 2007, Faktor-Faktor yang Mempengaruhi Minat Nasabah Menggunakan Internet Banking dengan Menggunakan Kerangka Technology Acceptance Model (TAM). Jurusan Ekonomi Akuntansi, Fakultas Ekonomi Universitas Kristen Petra.

Sherina dan Suartana, 2014. "Analisis Technology Acceptance Model (TAM) Terhadap Penggunaan Sistem Informasi Di Nusa Dua Beach Hotel \& Spa" E-Jurnal Akuntansi Universitas Udayana, ISSN: 2302-8556 (2014),h.168-169.

W.M. Lim and H. D. Ting, "E-Shopping: An Analysis of the Technology Acceptance 
Model," Modern Applied Science, vol. 6, no. 4,pp. 49-62, 2012

Y. Hwang dan M. Y. Yi, Predicting the Use of Web Based Information System: Intrinsic Motivation and Self Efficacy, in Eighth Americas Conference on Information Systems, Texas, USA, 2002.

Yusoff, Y. M., Zikri, M., Mohd, S. M. Z., Ermy, S. P., \& Emmaliana, R., 2009. "Individual Differences, Perceived Ease of Use, and Perceived Usefulness in the E-Library Usage" Computer and Information Science. Vol. 2, No. 1. 